\title{
Corporate Social Responsibility and Automotive Industry in the Czech Republic
}

\author{
Libuše SVOBODOVÁ ${ }^{*}$ and Dorota BEDNARSKA-OLEJNICZAK ${ }^{2}$ \\ 1 University of Hradec Kralove, Hradec Kralove, Czech Republic; libuse.svobodova@uhk \\ 2 Wroclaw University of Economics and Business, Wroclaw, Poland; dorota.bednarska-olejniczak@ue.wroc.pl \\ * Corresponding author: libuse.svobodova@uhk.cz
}

\begin{abstract}
The goal of the article is to analyse annual reports of the five most important businesses in the automotive industry in the Czech Republic and analyse their involvement in corporate social responsibility. The introduction part contains the explanation of basic concepts in the field of annual reports and corporate social responsibility. Results contains analysis of the annual reports of the selected companies and in the second part an analysis of the application of corporate social responsibility of analysed companies. The results of the analysis are evaluated at the end of the article. After the analysis, it can be evaluated that the best processed reports have a leader on the Czech automotive market, Škoda auto, JSC. Most of the analysed issues were reported by the companies. In the two companies are missing fight against corruption and bribery and in one respect for human rights. TATRA and Iveco are the less reporting companies about corporate social responsibility.
\end{abstract}

Keywords: automotive industry; Corporate Social Responsibility; reporting

JEL Classification: M14; M40

\section{Introduction}

Accounting can be defined as an activity leading to the determination of the state and changes of assets and their sources and the result of management for a certain period. It is in the interest of every business owner or investor to have an overview of whether his invested capital corresponds to the corresponding profit and whether the overall financial situation of the company is good. The primary task of accounting is therefore to provide a credible and active picture or financial situation of the company and for this purpose culminates several annual accounting works on the preparation of financial statements, which provides us with an overview of the financial situation. However, in connection with the end of the accounting period of companies, lot of companies do not prepare only financial statements. For reasons of legislative compliance also compile an annual report on a voluntary basis. The economic indicators of the company and data on the company's finances and performance form an integral part of the annual report. The annual report also includes information on the production of realized projections, business successes and recent corporate social responsibility. (Masiarová, 2020)

Corporate social responsibility (CSR) is generally understood as a voluntary obligation of companies to behave in a responsible way to the environment of society and the environment that affects their functioning. For this reason, the annual report can also be a 
corporate tool for the marketing and promotion system, any corporate social responsibility is more attractive to investors and builds a better image for the public.

(Moravcikova et al., 2015) presented that CSR is a trend that appeals to change of business orientation from short-term to long-term goals and from maximum to optimum profit. CSR reports, respectively triple-bottom-line reports have become tool of communication for Corporate Social Responsibility. Those are a voluntary comprehensive reports involving not only economic data, but also information from environmental and social field. These reports talk about the company policy in relationship to the environment, sustainability, or there are directly focused on fulfilling the commitments accepted by the company within the concept of social responsibility.

With effect from the accounting period beginning in 2017, a new obligation is set to provide so-called non-financial information in the Czech Republic. The presentation of nonfinancial information is defined in the Accounting Act No. 563/1991 Coll. in § 32f and § 32g. $\S 32 \mathrm{f}$ defines the scope, where the accounting entity presenting non-financial information means:

- A large entity that is a corporation and is also a public interest entity if, at the balance sheet date, it exceeds the criterion of an average of 500 employees during the accounting period.

- A consolidating entity of a large group of entities that is also a public interest entity if, at the balance sheet date, it exceeds the criterion of an average of 500 employees during the accounting period on a consolidated basis.

$\S 32 \mathrm{~g}$ states that an entity presenting non-financial information shall provide nonfinancial information to the extent necessary to understand the development of the entity or group, its performance and position and the effects of its operations. Between annual financial reports according to accounting act for selected accounting entities belongs:

- Basic information about the company.

- Information about the expected development of the entity.

- Non-financial information,

○ environment,

- social and employment issues,

- respect for human rights,

- fight against corruption and bribery.

- Financial Statements,

- balance sheet,

○ profit and Loss,

- attachment,

- cash flow statement,

- statement of changes in equity.

- Auditor's report on the audit of the financial statements. 
Dahlsrud (2008) came up with interesting findings regarding the definition of the concept of CSR in "How Corporate Social Responsibility is defined". According to the analysis of dozens of CSR definitions, Dahlsrud (2008) formulated five basic areas that appeared most frequently in the definitions. It's about:

- economic area,

- social area,

- environmental area,

- stakeholders,

- voluntariness.

Dahlsrud (2008) opinion is that although the existing definitions of CSR are formulated differently, they are in fact consistent, resp. they are congruent. He found that four of the five areas mentioned appeared in at least $80 \%$ of the definitions and three of the five areas even appeared in up to $97 \%$ of the definitions.

Based on several definitions, Tetřevová (2017) summarizes CSR as Corporate social responsibility representing such behavior of managers and other employees of the company, which respects not only the economic and technical interests of the company but also the interests of all corporate stakeholders and interweaves with all corporate activities.

(MacGregor Pelikánová, 2019) focused on CSR information in annual reports in the EU. She focused on the Czech case study. The 10 largest Czech companies are subjects of the legal duty to prepare and e-file with the Commercial Register their annual reports with CSR information, but this legal duty is set up in a rather general and vague manner. This leaves open a rather large discretionary space in its perception and satisfaction. The analysis was done between 2013-2017. Three of the analysed companies were from automotive industry.

(Myšková \& Hájek, 2018) focused on sustainability and CSR in the text of annual reports. They focused on IT services industry. The companies studied do present activity relating to sustainable development in their annual reports. It can be seen from the results above that information on activities in the field of CSR are primarily included in the annual reports; however, CSR was presented with a negative overtone, which does not correspond with the assumption that including a presentation of sustainable development and especially CSR activities in annual reports would target a positive perception of the company by stakeholders. The analysis was done in 2014 and 2015.

Currently, increasing attention is being paid to the issues of sustainability and social responsibility. The measure of a company's success is not only its profitability, but rather its overall evaluation relies on quantitative and qualitative characteristics, increasingly reflecting the company's interaction with its surroundings. Therefore, a company's competitiveness is linked not only to economic outcomes, but also to how the company meets its stakeholders' expectations as to the activities it develops for reasons of CSR and sustainable development. (Crane \& Glozer, 2016; Lim \& Greenwood, 2017; Seele \& Gatti, 2017).

According to KMPG study (2020) the Czech Republic is in the sustainability reporting rates lower than the global average (less than $77 \%$ ). But there is the optimistic trend. While 
in 2017 was the rate 51\%, in 2020 66\%. The best countries and jurisdictions with reporting are Japan, Mexico, Malaysia, India, US, Sweden, Spain and France.

Regulators of capital markets should use CSR information as guidelines to improve financial reporting quality and achieve better allocation of resources in capital markets. (Kareem AL Ani, 2021)

Accounting researchers have become increasingly interested in CSR, which has received notable attention in accounting and finance. Traditionally, CSR integrates social activities and business activities. (Moser \& Martin, 2012) point out that the firms engage in socially responsible activities when they conduct business activities. Within the same framework, (Budianto \& Suyono, 2020) believe that CSR is a genuine effort by business entities to minimise negative impacts and maximize the positive impact of its operations.

The necessity of communication and use of social media was presented in (Svobodová et al., 2019). Use of CSR is also connected with financial literacy. The portals in the Czech Republic were discussed in (Hedvicakova \& Svobodova, 2018). The Czech Republic and its technological readiness is on an appropriate level (Svobodova \& Hedvicakova, 2017). Evaluation of cluster initiatives that can be used also in CSR is presented in Bureš et al. (2012). Situation in Slovak automotive industry analysed (Richnák \& Gubová, 2021). Based on the research, they found that the dominant position in green and reverse logistics in Slovakia was achieved by large production enterprises from the automotive industry, which operate in western Slovakia. The analysed enterprises in Slovakia use voluntary tools of environmental policy and the most important environmental tool is corporate social responsibility.

The main fields (economic, social and ecological) presented in previous articles focused on CSR are presented in Figure 1.

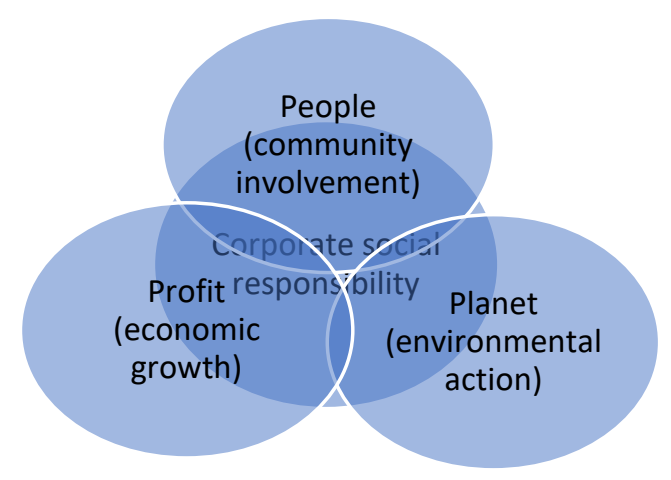

Figure 1. The main parts of Corporate Social Responsibility (own processing)

\section{Methodology}

The article consists of two parts. The first part is focused on introduction and literature review. The theoretical basis related to the issue of financial statements and annual reports will be clarified. It will be also described which parts of the financial statements consist of 
and which entities are required to be audited. Subsequently, the basic approaches to corporate social responsibility will be described and their benefits will be explained.

The second part of the article contains the analysis of individual companies selected to analyse their annual reports and social responsibility. For these companies, selected requirements of the annual reports will be evaluated, whether they contain selected data and what is their overall transparency. Subsequently, the same companies will be described and compared their activities in the field of social responsibility.

At the end of the work will be summarized the basic findings from the analysis of annual reports and corporate social responsibility. From these findings, certain recommendations for individual car manufacturers will also emerge.

This work aims to compare and evaluate the annual reports of selected companies, especially in terms of completeness of financial statements and also to compare these companies' involvement in social responsibility.

The aim of the article is to analyse the reporting of selected companies in the framework of financial accounting and social responsibility. The automotive industry in the Czech Republic was chosen as the sector to be researched, in which the largest manufacturers include:

- Škoda Auto, JSC

- Hyundai Motor Manufacturing Czech, ltd. (HMMC)

- Toyota Peugeot Citroën Automobile Czech ltd. (TPCA)

- Tatra Trucks, JSC

- Iveco Czech Republic, JSC

The results of the research will include the results of the performed analyses of the annual reports of individual companies for the year 2014-2019, i.e. their completeness will be assessed according to the accounting act. In the tables 1 and 2 will be presented data only for 2019, because results are almost the same for all years. Differences will be mentioned in the text. The author chose the criteria of annual reports mainly according to the requirements stipulated by law. The criteria of non-financial information were divided in detail according to the obligations from the amendment to the accounting act of 2017, which imposes the obligation to report non-financial indicators to large companies. In the text will be companies presented without type of business according to law.

\section{Results}

Results part will describe the activities of social responsibility of individual automotive companies in the Czech Republic. According to the theoretical part, the author decided to divide these activities into three basic areas. At the same time, sub-areas have been created that will help to identify the company's social responsibility. The source of all used and analysed data is the websites of individual companies or their annual reports. 


\subsection{Summary of the Analysis of Annual Reports}

Annual reports of Škoda Auto during the six-year period under review, they meet all selected requirements and, in addition, the company publishes many other activities in them, thus building a valuable image, thus becoming credible for current investors and the same time attractive for new investors.

Annual reports of Hyundai Motor Manufacturing Czech for 2015 and 2016 contain all mandatory selected requirements, but the annual reports from 2017-2019 lack non-financial information on the fight against corruption and bribery in the company.

At Toyota Peugeot Citroën Automobile only the first three met all the requirements from the analysed annual reports; in 2017-2019 there was again a problem with the reporting of non-financial information, as there were no points to respect human rights and to fight corruption. Overall, not all of the company's annual reports are as comprehensive as the previous ones and are apparently prepared for the sole purpose of meeting legislative requirements.

From the legislative point of view, the company Tatra Trucks met all selected financial requirements of the annual reports. But as for the graphic design of the annual reports, apparently even for this company, the annual reports do not belong to promotional or marketing material, as they are just as formal as for Toyota Peugeot Citroën Automobile.

Annual reports of Iveco Czech Republic are more comprehensive and readable in terms of the content of non-financial information and information on the future development of the company than is the case with TPCA and Tatra. In addition to the non-fulfillment of the obligation to publish non-financial information on the fight against corruption and bribery in 2017-2019, the annual reports meet all selected requirements. (see Table 1) Overall, the annual reports of Škoda Auto and Hyundai Motor Manufacturing are prepared the best, worse are prepared the annual reports of Iveco Czech Republic and Toyota Peugeot Citroën Automobile.

Table 1. Details of the annual report of the analysed companies in 2019. (annual reports of Škoda, HMMC, TPCA, TATRA and IVECO)

\begin{tabular}{|c|c|c|c|c|c|}
\hline Details of the annual report & Škoda & HMMC & TPCA & TATRA & IVECO \\
\hline Basic information about the company & Yes & Yes & Yes & Yes & Yes \\
\hline $\begin{array}{c}\text { Information about the expected } \\
\text { development of the entity }\end{array}$ & Yes & Yes & Yes & Yes & Yes \\
\hline Non-financial information & Yes & No & No & Yes & No \\
\hline environment & Yes & Yes & Yes & Yes & Yes \\
\hline social and employment issues & Yes & Yes & Yes & Yes & Yes \\
\hline respect for human rights & Yes & Yes & No & Yes & Yes \\
\hline fight against corruption and bribery & Yes & No & No & Yes & No \\
\hline Financial Statements & Yes & Yes & Yes & Yes & Yes \\
\hline balance sheet & Yes & Yes & Yes & Yes & Yes \\
\hline profit and loss & Yes & Yes & Yes & Yes & Yes \\
\hline attachment & Yes & Yes & Yes & Yes \\
\hline cash flow statement & Yes & Yes & Yes & Yes \\
\hline statement of changes in equity & Yes & Yes & Yes & Yes & Yes \\
\hline Auditor's report on the audit of the & & & & & Yes \\
\hline financial statements & & & & \\
\hline
\end{tabular}


In case that we compare results of annuals reports from 2014-2019, almost all items were the same. The difference was in Tatra Trucks. They didn't focus on respect for human rights and fight against corruption and bribery in 2014. From 2015 they report those information.

\subsection{Summary of the Comparison of Social Responsibility}

To clearly present the involvement of individual companies in social responsibility, three basic areas were determined according to the literature review in the article. This is an economic, social and environmental area. The social responsibility of selected companies was most pronounced in the social and environmental areas, for this reason these areas were divided into other points determined according to the published data of the analysed companies. The social area contains according to field of companies support for technical education, traffic safety, support for the disabled, support for disadvantaged children and support for regions. In the environmental area were included environmental protection and recyclability.

The company Škoda Auto more than $100 \%$ fulfilled all selected areas of social responsibility. Many long-term projects are aimed at each of the areas and in comparison with other automotive manufacturers in the Czech Republic, this company is clearly the most involved in the issue of social responsibility.

The Hyundai Motor Manufacturing Czech and Toyota Peugeot Citroën Automobile also focus on all selected categories of social responsibility, but in some areas they are only involved in one project.

The company Tatra Trucks fulfills one hundred percent only the economic area, in other areas it does not present specific activities. These are the areas of support for the disabled, support for the disadvantaged children and recyclability issues.

At Iveco Czech Republic the economic area of social responsibility is fulfilled, the other areas are fulfilled in part. In the social field, the company's involvement in activities supporting technical education, road safety and regional support is lacking. In the environmental field, addressing recyclability issues.

The fulfillment of selected areas of social responsibility of all analysed companies is clearly shown in the following table, (see Table 2).

Table 2: Selected areas of social responsibility of the analysed companies in 2019 (annual reports and websites of Škoda, HMMC, TPCA, TATRA and IVECO)

\begin{tabular}{|c|c|c|c|c|c|}
\hline & Škoda & HMMC & TPCA & TATRA & IVECO \\
\hline Economic area & Yes & Yes & Yes & Yes & Yes \\
\hline Social area & Yes & Yes & Yes & Yes & Yes \\
\hline support for technical education & Yes & Yes & Yes & No & Yes \\
\hline traffic safety & Yes & Yes & Yes & Yes & No \\
\hline support for the disabled & Yes & Yes & Yes & No & No \\
\hline support for disadvantaged children & Yes & Yes & Yes & No & Yes \\
\hline support for regions & Yes & Yes & Yes & Yes & Yes \\
\hline Environmental area & Yes & Yes & Yes & Yes & Yes \\
\hline environmental Protection & Yes & Yes & Yes & Yes & Yes \\
\hline recyclability & Yes & Yes & Yes & No & No \\
\hline
\end{tabular}




\section{Discussion and Conclusions}

The aim of this article was to compare and evaluate the annual reports of selected companies, especially in terms of completeness of financial statements and at the same time to compare their involvement in social responsibility for these companies. From the results of the analysis of the annual reports of the companies of the automotive industry in the Czech Republic, it was found that only some companies prepare annual reports carefully and pay attention to the newly created obligations in financial reporting. Often even companies do not use the full potential of this document as a marketing and promotional tool. On the contrary most of the required data are by the automotive companies reported.

Corporate social responsibility in the automotive industry of the Czech Republic is mainly engaged in by companies with greater market power, as is evident especially in the case of Škoda Auto and HMMC which show a high level of environmental activity. They organize events not only for employees, but also for the general public and generally contribute to a positive public view of their socially oriented activities. Almost all companies reported all monitored issues and the level of corporate social responsibility is in the analysed companies on the high levels.

The area of environmental responsibility is currently particularly important in the automotive industry, as this industry is already making a significant contribution to the harmful effects of the environment in the form of emissions through its production. Unfortunately, it is the same with the product, which also pollutes the air during its use. It is precisely because of these facts that it is necessary for companies in this industrial area to adapt their production process and the development of new products towards environmental friendliness and sustainability.

(Russo-Spena et al., 2018) focuses on the similar issues as authors of the article. Based on a longitudinal study of CSR reports of companies operating in the automotive industry, the paper offers a detailed study of how disclosure practices are changing and which principles and approaches influence and drive the development of such disclosure. Based on a fouryear report-based study, the findings enable us to identify three main trends in the CSR disclosure strategy of automotive firms. First, in line with the mainstream CSR literature, the present study confirms the trend towards the increasing environmental and social accountability. Second, it adds evidence to the emerging debate regarding the harmonization and standardization of reporting and discusses this aspect by mentioning the standards as exerting some normative pressures within the sector. Finally, it provides evidence on specific links emerging between issues and actors.

Acknowledgments: We would like to thank to project "SPEV - Economic Impacts under the Industry 4.0 / Society 5.0 Concept ", 2021, University of Hradec Králové, Faculty of Informatics and Management, Czech Republic“ and to Anna Borkovcová.

\section{References}

Act no. 563/1991, accounting. Czech Republic. The Parliament of the Czech Republic. https://www.zakonyprolidi.cz/cs/1991-563 
Budianto, R., \& Suyono, E. (2020). Corporate Social Responsibility and Factors Affecting It: An Empirical Evidence from the Indonesian Capital Market. International Journal of Economics and Business Administration, 8(1), 239-253. https://doi.org/10.35808/ijeba/422

Bureš, V., et al. (2012). A Comprehensive View on Evaluation of Cluster Initiatives. In J. Politis (Eds.), Proceedings of the 8th European conference on management leadership and governance (pp. 74-79).

Crane, A., \& Glozer, S. (2016). Researching Corporate Social Responsibility Communication: Themes, Opportunities and Challenges. J. Manag. Stud., 53, 1223-1252. https://doi.org/10.1111/joms.12196

Dahlsrud A. (2008). How corporate social responsibility is defined: an analysis of 37 definitions. Corporate Social Responsibility and Environmental Management, 15(1), 1-13. https://doi.org/10.1002/csr.132

Decree No. 500/2002. Decree implementing certain provisions of Act No. 563/1991, on accounting, as amended, for accounting entities that are entrepreneurs accounting in the double-entry bookkeeping system

Hedvicakova, M., \& Svobodova, L. (2018). Web Portals Used in Financial Education as a Support of Financial Literacy. Advanced Science Letters, 24(4), 2948-2952. https://doi.org/10.1166/asl.2018.11102

Hyundai Motor Manufacturing Czech. (2020). Annual report 2019. Hyundai Motor Manufacturing Czech. https://or.justice.cz/ias/ui/vypis-sl-firma?subjektId=245382

Hyundai Motor Manufacturing Czech. (2021). Hyundai. https://www.hyundai.cz/

Iveco Czech Republic. (2020). Annual report 2019. Iveco Czech Republic. https://or.justice.cz/ias/ui/vypis-slfirma?subjektId=126335

Iveco Czech Republic. (2020). IVECO Czech Republic. https://www.ivecocr.cz/

Kareem AL Ani, M. (2021). Corporate social responsibility disclosure and financial reporting quality: Evidence from Gulf Cooperation Council countries. Borsa Istanbul Review, S2214845021000065. https://doi.org/10.1016/j.bir.2021.01.006

KPMG. (2020). The KPMG Survey of Sustainability Reporting 2020.

https://assets.kpmg/content/dam/kpmg/be/pdf/2020/12/The_Time_Has_Come_KPMG_Survey_of_Sustaina bility_Reporting_2020.pdf

Lim, J. S., \& Greenwood, C. A. (2017). Communicating Corporate Social Responsibility (CSR): Stakeholder Responsiveness and Engagement Strategy to Achieve CSR Goals. Public Relat. Rev., 43, 768-776. https://doi.org/10.1016/j.pubrev.2017.06.007

MacGregor Pelikánová, R. (2019). Corporate Social Responsibility Information in Annual Reports in the EU-A Czech Case Study. Sustainability, 11, 237. https://doi.org/10.3390/su11010237

Masiarová, N. (2020). Analysis of annual reports and social responsibility of selected companies. Diploma thesis.

Moravcikova, K., Stefanikova, L'., \& Rypakova, M. (2015). CSR Reporting as an Important Tool of CSR Communication. Procedia Economics and Finance, 26, 332-338. https://doi.org/10.1016/S2212-5671(15)00861-8

Moser, D. V., \& Martin, P. R. (2012). A Broader Perspective on Corporate Social Responsibility Research in Accounting. The Accounting Review, 87(3), 797-806. https://doi.org/10.2308/accr-10257

Myšková, R., \& Hájek, P. (2018). Sustainability and Corporate Social Responsibility in the Text of Annual Reports-The Case of the IT Services Industry. Sustainability, 10, 4119. https://doi.org/10.3390/su10114119

Richnák, P., \& Gubová, K. (2021). Green and Reverse Logistics in Conditions of Sustainable Development in Enterprises in Slovakia. Sustainability, 13(2), 581. https://doi.org/10.3390/su13020581

Russo-Spena, T., Tregua, M., \& De Chiara, A. (2018). Trends and Drivers in CSR Disclosure: A Focus on Reporting Practices in the Automotive Industry. Journal of Business Ethics, 151(2), 563-578. https://doi.org/10.1007/s10551-016-3235-2

Seele, P., \& Gatti, L. (2017). Greenwashing Revisited: In Search of a Typology and Accusation-Based Definition Incorporating Legitimacy Strategies: Greenwashing Revisited. Bus. Strategy Environ, 26, 239-252. https://doi.org/10.1002/bse.1912

Svobodová, L., Černá, M., Olejniczak, J., \& Bednarska-Olejniczak, D. (2019). Utilization of Social Media Network in Automotive Industry in the Czech Republic: Case-study. In Jedlička, P., Marešová, P., \& Soukal, I. (Eds.), Proceedings International scientific conference Hradec Economic Days 2019 (pp. 370-381).

https://doi.org/10.36689/uhk/hed/2019-02-038

Svobodova, L., \& Hedvicakova, M. (2017). Technological Readiness of the Czech Republic and the Use of Technology. In M. Themistocleous, \& V. Morabito (Eds.), Information Systems (Vol. 299, pp. 670-678). Springer Berlin Heidelberg. https://doi.org/10.1007/978-3-319-65930-5_53

Škoda Auto. (2020). Annual reports 2019. Škoda Auto. https://or.justice.cz/ias/ui/vypis-sl-firma?subjektId=47718

Škoda Auto. (2020). Škoda Auto. https://www.skoda-auto.cz/

Škoda Auto. (2020). Corporate Governance Škoda Auto. https://www.skoda-auto.cz/o-nas/corporate-governance 
Škoda Auto. (2020). Corporate social responsibility. Škoda Auto. https://www.skoda-auto.cz/o-nas/spolecenskaodpovednost-dopravni-bezpecnost

Tatra Trucks. (2020). Annual report 2019. Tatra Trucks. https://or.justice.cz/ias/ui/vypis-sl-firma?subjektId=274834

Tatra Trucks. (2020). Tatra Trucks. https://www.tatra.cz/

Tetřevová L., et al. (2017). Social responsibility of companies in socially sensitive sectors. Grada Publishing

Toyota Motor Manufacturing Czech Republic. (2020). Annual report 2019. Toyota Motor Manufacturing Czech Republic. https://or.justice.cz/ias/ui/vypis-sl-firma?subjektId=238739

Toyota Motor Manufacturing Czech Republic. (2020). TPCA. https://www.tpca.cz/ 